\title{
Holdninger blant studenter i barnehagelærerutdanningen til barn med særskilte behov
}

The attitudes among students in the kindergarten teacher education to children with special needs

\author{
Vivian D. Haugen \\ Dosent i spesialpedagogikk \\ UiT, Norges Arktiske universitet. Institutt for lærerutdanning og pedagogikk ILP. \\ vivian.d.haugen@uit.no
}

\section{Sammendrag}

Artikkelen belyser holdninger til barn med sarskilte behov blant studenter $i$ barnehageloererutdanningen. Ved hjelp av et eksperimentelt design er det undersøkt om studentene utvikler mer positive holdninger til barn med scerskilte behov fra de starter studiet til de avslutter studiet. Resultatene viser en signifikant økning i positiv holdning i løpet av studiet. Denne økningen er uavhengig av studentenes alder og kjønn. Undersøkelsen gir en indikasjon på at utdanning er viktig for utviklingen av positive holdninger til barn med sarskilte behov, noe som er viktig i debatten om hvem som bør ha ansvaret for og jobbe med barn med rett til spesialpedagogisk hjelp i barnehagen.

\section{Nøkkelord}

holdning, holdningsendring, barn med særskilte behov, barnehagelærerutdanningen

\section{Summary}

The article focuses on attitudes to children with special needs among students in kindergarten teacher education. With the use of an experimental design, it has been investigated whether the students develop more positive attitudes towards children with special needs from the time they start their studies until they finished their studies. The results indicates a significant increase in positive attitude during the study. This increase is independent of the students' age and gender. The survey shows that education is important for the development of positive attitudes towards children with special needs, which is important in the debate about who should be responsible for working with these children.

\section{Keywords}


attitude, change in attitude, children with special needs, kindergarten teacher education

\section{Begrepet holdning}

En vanlig oppfatning av begrepet holdning er at det inneholder en kunnskapskomponent og en emosjonell komponent som gir seg utslag i en eller annen form for handling mot personer, situasjoner eller fenomener.

\section{Etablering av holdninger}

Når en person uttrykker seg positivt eller negativt om noen eller noe, så er det på bakgrunn av de erfaringer som er gjort i den kulturen personen har vokst opp. Det vil si at de rådende verdier som eksisterer i en bestemt kultur eller subkultur, utgjør de grunnleggende påvirkningsagentene for utvikling eller etablering av en persons holdninger. I de første årene er det foreldrenes holdninger og væremåte som normalt vil være de mest sentrale påvirkningsagentene for etablering av det oppvoksende barnets holdninger. De erfaringene barnet gjør er ikke i stor grad basert på kunnskap eller innsikt om et emne, men erverves ganske ureflektert fra foreldrene. Når et barn gjør foreldres holdninger til sine egne, skjer det vanligvis ved internalisering. Internalisering er en sentral del av sosialiseringsprosessen. Holdning blir derfor et resultat av en lærings- eller erfaringsprosess som det enkelte barn gjør i den spesifikke familiekonstellasjon som det er en del av.

Etter hvert vil venner og andre for barnet betydningsfulle personer påvirke holdningsdannelsen selv om kunnskapen om emnet kan være noe ureflektert. Det er viktig for en ungdom å kunne identifisere seg med en jevnaldringsgruppe. Sett på bakgrunn av dette vil holdninger være et resultat av den sosialiseringskultur som den enkelte person har vært en del av. Lines (2005) mener holdninger er lettere å forme enn å endre på. Dette siden en person har en tendens til selektivt å velge ut, og vil også huske best den informasjonen som støtter egne holdninger (Busch \& Wennes 2012). Dette kan derfor bidra til at holdninger som formes gjennom sosialiseringsprosessen, vanskeligere lar seg endres siden informasjon som er inkonsistent med egne holdninger, avvises eller aktivt motargumenteres (ibid.).

Forskning viser imidlertid at også personlighetstrekk kan ha innvirkning på en persons endring av holdninger. Vakola, Tsaousis og Nikolaou (2004) viser til at ekstroverte, samvittighetsfulle, åpne og imøtekommende personer i større grad er mottakelig for endringer enn personer med lav skåre på disse personlighetstrekkene. Den samme positive endringseffekten ble registrert hos personer med høy emosjonell intelligens. En persons 
personlighetstrekk er relativt stabil og vil derfor ha innvirkning på hvor raskt en holdningsendring vil inntre.

\section{Definisjoner av holdning}

En generell definisjon av holdning er fremsatt av Katz (1960) som definerer holdning eller "attitude" som "the predisposition of the individual to evaluate some symbol or object or aspect of this world in a favorable or unfavorable manner" (s. 168). I denne relativt generelle definisjonen framgår det at holdningen en person har til et eller annet, er forankret i det Katz benevner predisposisjon. Hva denne predisposisjonen består av, sies det ikke noe om. Secord og Beckman (1969) knytter holdninger til predisposisjoner ved å definere holdning som en tendens i en persons følelser, tanker og predisposisjoner til å handle mot et aspekt i miljøet.

Arnold, Cooper og Robertson (1995) definerer holdning som «a person's tendency to feel, think and behave in a positive or negative manner towards the object of the attitude» (s. 167). Holdning innebærer en positiv eller negativ tilbøyelighet eller handlingstendens overfor person(er), situasjon(er) eller fenomen(er). Holdning viser seg blant annet i en persons måte å snakke positivt eller negativt til eller om andre personer på eller uttrykke seg positivt eller negativt om situasjoner eller fenomener i skrift eller handling. Holdninger utgjør derfor en sentral del av en persons personlighet og er beslektet med personens verdier og oppfatninger.

Definisjoner som understreker atferdskomponenten: Atferdsdimensjonen trekkes inn av English og English (1958) når de definerer holdning som: "Attitude is an enduring learned predisposition to behave in a consistent way toward a given class of objects" (s. 50). Her poengteres det også at predisposisjonen er lært. Atferdselementet trekkes også inn av Campbell (1950) som definerer holdning som: "An attitude is a syndrome of response consistency with regard to a set of social objects" (s. 31). Hildgard og Atkinson (1967) erstatter uttrykket predisposisjon med "orienteering” når de uttrykker: "Attitude is an orientation towards or away from some object, concept, or situation, and a readiness to respond in a predetermined manner to these, or related objects, concepts, or situations" (s. $583)$.

Definisjoner som understreker den kognitive komponenten: Det kognitive elementet $\mathrm{i}$ holdningsbegrepet ble introdusert av Allport allerede i 1935 når han definerer begrepet som: "Attitudes are individual mental processes which determine the actual and potential responses of each person in a social world" (s. 6).

Definisjoner som understreker den affektive komponenten: Det affektive elementet i holdningsbegrepet poengteres av Fishbein (1967) når det uttrykkes: “Attitude is a learned 
predisposition to respond to an object or class of objects in a consistently favorable or unfavorable way" (s. 257). Thurstone (1946) uttrykker det affektive aspektet ennå mer direkte: "Attitude is the degree of positive or negative affect associated with some psychological object" (s. 39). Lines 2005 viser til at emosjoner i seg selv kan bidra til holdningsendringer om endringen har egenskaper som assosieres med negative eller positive emosjoner som kan prege holdningsutviklingen.

Definisjoner av holdning som understreker to komponenter: Bogardus (1931) trekker inn både atferdselementet og det affektive elementet når holdning defineres som: "An attitude is a tendency to act toward or against some environmental factor which becomes thereby a positive or negative value" (s. 52).

Definisjon av holdning som innlemmer alle dimensjoner i definisjonen: Triandis (1971) har en definisjon som innlemmer tre komponenter i definisjonen, nemlig en kognitiv komponent, affektiv komponent og en atferdskomponent: "An attitude is an idea charged with emotion which predisposes a class of actions to a particular class of social situations" (s. 2).

\section{Holdningsbegrepets komponenter}

Som det framgår av definisjonen i det foregående, er det en vanlig oppfatning blant forskere at begrepet holdning kan sies å bestå av to hovedkomponenter, nemlig en kognitiv eller kunnskaps- eller vitensdel og hva man føler eller opplever knyttet til det man har en holdning om eller til, nemlig en emosjonell komponent.

Holdningsbegrepets kunnskapskomponent: Det som en person vet eller har av kunnskap og som inngår i det personen har en holdning til, trenger ikke være fundert i korrekt eller sikker viten. Ofte beror negative holdninger, for eksempel en negativ holdning til funksjonshemmede, på ufullstendige eller manglende/feilaktig kunnskap om gruppen av personer med funksjonshemning. Dette tilsier at endring av en negativ holdning til denne gruppen mennesker skulle ha gode muligheter for å kunne endres i positiv retning dersom personen får korrigert sin feilaktige viten om gruppen funksjonshemmede.

Holdningsbegrepets emosjonelle komponent: Når man gir uttrykk for noe positivt eller negativt uavhengig om det beror på korrekt viten eller ei, så må emosjoner være forbundet med den viten personen har om temaet. Jo sterkere positiv eller negativ holdning en person måtte besitte overfor en persongruppe eller et fenomen, desto sterkere er følelsene involvert. En sterk negativ holdning til noe, som for eksempel når høyreekstreme uttaler seg om innvandrere, er sannsynligvis forbundet med sterke negative følelser som hat og avsky. Denne følelsen som inngår i holdningen, er sannsynligvis også rettet mot personer tilknyttet politiske 
partier som vil øke innvandringen.

Dersom følelseskomponenten er fraværende, eller det ikke inngår følelser i en persons synspunkter på et eller annet, så er det ikke en holdning, men en mening eller en nøytral oppfatning av noe. Generelt er det grunn til å anta at negative holdninger er forbundet med negative følelser som mistenksomhet, motvilje og manglende interesse, mens positive holdninger er forbundet med åpenhet og positive følelser i form av interesse og engasjement for et tema eller en persongruppe. Positive holdninger er vanligvis også forbundet med indre motivasjon til noen eller noe.

Holdningsbegrepets handlingskomponent: For å kunne bestemme eller registrere en persons holdning om eller til et eller annet, så må holdningen manifestere seg eller vise seg på en eller annen måte. Denne manifesteringen kommer hyppigst til uttrykk når folk snakker positivt eller negativt om noe eller noen. Men holdninger kommer også ofte til uttrykk i form av skrift slik som blogger, leserinnlegg eller kronikker. For at politiske partier skal kunne påvirke folk til å få en positiv holdning til det budskapet partiet forsøker å «selge», så blir taler, diskusjoner og debattinnlegg i aviser viktige måter å gi uttrykk for de holdninger partiet står for eller representerer.

I undervisningssituasjoner i barnehagelærerutdanningen påvirkes studentene ved at de får kunnskap om barn, barns utvikling (kunnskapskomponenten) og dessuten blir gjort kjent med barn som av en eller annen grunn ikke har det så bra, eller barn som ikke utvikler seg som forventet ut fra alder. Det er naturlig å anta at det siste aspektet er særlig relevant for holdningsbegrepets emosjonelle komponent. Holdningsbegrepets atferdskomponent kommer særlig til uttrykk i gruppediskusjoner og ikke minst i studentenes praksis i barnehagen der deres ferdigheter kan registreres. En students ferdighet i det daglige arbeidet $\mathrm{i}$ barnehagen vil i stor grad reflektere handlingskomponenten i holdningsbegrepet. Det gjelder holdning til barn generelt og holdning til barn med særskilte behov spesielt.

\section{Holdning og konflikt}

En persons holdning til noe kan komme i konflikt med det personen gjør. En måte å redusere denne uoverensstemmelsen kan være å endre det kognitive aspektet eller vitenaspektet. Dette har Festinger (1957) vist i sitt berømte eksperiment. Han fant fram til tre grupper av personer der gruppe 1) var ikke-røkere, i gruppe 2) røkte personene moderat, mens alle i gruppe 3) var storrøkere. De tre gruppene skulle ta stilling til spørsmålet om de «trodde på», «trodde i noen grad» eller «ikke trodde på» de begynnende forskningsresultater rundt 1950 som indikerte en 
sammenheng mellom røyking og lungekreft».

Resultatene viste ikke overraskende at ikke-røkerne festet lit til resultatene, gruppe 2 var mer usikre på funnene, men gruppe 3 (storrøykerne) ikke trodde på resultatene om sammenhengen mellom røyking og lungekreft. Festingers undersøkelse gir en god indikasjon på at mennesker forsøker å oppnå balanse mellom hva de gjør (handlingskomponent) og den kognitive komponenten, kunnskap eller oppfatning (vitenkomponent).

Fordom: Enkelte holdninger kan være vanskelig å endre. Fordommer er vanligvis forankret i feilaktig eller ufullstendig kunnskap om en persongruppe eller et emne og er forbundet med negative følelser. Ofte vil vanlige metoder for endring av holdninger ha liten innvirkning på en person med en eller flere fordommer om noen eller noe eller til noe.

\section{Forskning som er relatert til holdning til barn med særskilte behov}

Det har ikke lykkes å finne undersøkelser som direkte undersøker eventuell endring i holdning til barn med særskilte behov der gruppen som skal undersøkes, har vært utsatt for en eller annen påvirkning, for eksempel undervisning som har foregått en viss periode. De undersøkelser som en har funnet fram til, har kartlagt grupper av personers holdning til barn med særskilte behov, læreres holdning til integrering og inkludering (inclusion/mainstreaming) av barn med særskilte behov i den ordinære skolen og personers holdning til spesifikke grupper av barn, for eksempel holdning til barn med ADHD eller barn med lærevansker. I noen undersøkelser ser forskerne på eventuelle forskjeller i holdning mellom personer som har gjennomgått et kurs eller opplæringsprogram relatert til barn med særskilte behov versus personer som ikke har gjennomgått et kurs eller opplæringsprogram relatert til barn med særskilte behov.

\section{Forskning om loereres syn på inkludering}

Avramidis, Bayliss og Burden (2000) undersøkte læreres holdning til inkludering av barn med særskilte opplæringsbehov (special educational needs) i vanlig skole i England. Utvalget besto av 81 lærere i barneskole og videregående skole. Forskerne fant at de lærere som hadde gjennomgått et innføringsprogram (inclusive programmes) relatert til integrering/inkludering, framviste mer positive holdninger til barn med særskilte behov sammenlignet med de lærere som ikke hadde fått den innføringen.

Hwang og Evans (2011) undersøkte 33 koreanske lærere i barneskolen om deres holdning til barn med særskilte behov og lærernes villighet til å ta hensyn til disse elevene i den praktiske hverdag i skolen. Resultatene viser at 41,3\% av grunnskolelærere hadde 
positive holdninger til inkluderingsprogrammer mens 55,2\% var uvillige til å delta i dette. Denne undersøkelsen viser at det man gjør, eller bør gjøre, ikke alltid harmonerer med den holdning man har eller den holdning man gir uttrykk for å besitte.

Monsen og Frederickson (2004) undersøkte grunnskolelæreres holdning til inkludering og myndighetenes rådende syn på inkludering av barn med særskilte behov i skolen. Lærerne ble kategorisert i 3 grupper avhengig av hva de svarte på et spørreskjema. Disse gruppene (høy positiv holdning, moderat positiv holdning og lav positiv holdning til inkludering) ble så sammenlignet med svar elevene til de respektive lærere hadde på undervisningen de mottok. Resultatene viste at elevene som ble undervist av lærere med høy positiv holdning til inkludering, ga uttrykk for høy grad av trivsel og mindre konflikter sammenlignet med elevene som ble undervist av lærere med moderat og lav holdning til barn med særskilte behov.

\section{Forskning om lcereres og studenters holdning til barn med en definert}

\section{funksjonssvikt}

Bekle (2004) undersøkte om det eksisterer eventuelle forskjeller i syn på holdning til barn med ADHD mellom grunnskolelærere og studenter i pedagogikk. Det ene utvalget besto av 30 lærere fra vest i Australia, mens utvalget av studenter $(\mathrm{N}=40)$ var tilknyttet universitetet i Perth. Undersøkelsen viste at begge grupper hadde tilfredsstillende kunnskap om barn med ADHD, selv om lærergruppen kunne framvise noe mer faktakunnskap. Et interessant funn var at både læreres og studenters grad av kunnskap var positivt korrelert med holdningen de hadde til barn med ADHD. Dette understreker kunnskapskomponentens betydning i holdningsbegrepet.

Brook, Watemberg og Geva (2000) undersøkte lærere på videregående skole og deres kunnskap om og holdning til barn med ADHD og lærevansker. Utvalget besto av 46 høyskolelærere i Israel som ble intervjuet. Lærerne kunne kategoriseres i to grupper der en lærergruppe underviste ved en akademisk skole (skole 1) mens den andre gruppen av lærere underviste ved en spesialskole der barn med ADHD og lærevansker var relativt hyppig forekommende. Resultatene viste at generell kunnskap om ADHD og lærevansker var relativ lav i begge grupper av lærere. Spesialskolelærerne (skole 2) framviste noe mer positiv holdning enn lærerne ved skole 1 . Hele 13 prosent av lærerne mente av årsaken til lærevansker var foreldreholdninger, det vil si at foreldrene skjemte bort barna. Dette resultatet sier noe om hva sviktende kunnskap har å si for holdningen til det man har sviktende kunnskap om. 
En undersøkelse gjennomført av Park, Chitiyo og Choi (2010) gjelder læreres syn på barn med autisme i USA. Utvalget var studenter som fulgte et utdanningsprogram for lærere ved et college i USA. Resultatene viste at lærerstudentene hadde positive holdninger til barn med autisme. Disse resultatene bare understreker kunnskapskomponentens betydning i oppbyggingen av en positiv holdning til barn med spesielle behov.

\section{Kort oppsummering med forventning}

Det er redegjort for at begrepet holdning består av to hovedkomponenter, nemlig en kunnskapskomponent og en holdningskomponent. Når en innlemmer hvordan holdninger viser seg i praksis som i skrift, tale eller handlinger eller ferdigheter, så består holdningsbegrepet av tre komponenter.

Med utgangpunkt i de refererte forsøk, så er det en klar indikasjon på den betydning kunnskapskomponenten har for en positiv holdning til barn med særskilte behov. Det er all grunn til å konkludere med at skal holdningsendring finne sted, så må studenter, lærere eller andre personer motta saklig og informativ kunnskap om emnet. Selv om kunnskapskomponenten kan framstå som svært viktig i holdning og holdningsendring, så er den emosjonelle komponenten vanligvis innbakt i kunnskapskomponenten.

Atferdskomponenten kommer til uttrykk i hva personen sier, skriver eller gjør. I en undervisningssituasjon vil atferds- eller handlingskomponenten også kunne vise seg i studentens eller barnehagepedagogens ferdighet $\mathrm{i}$ å omgås og forholde seg til barn.

Hypotese: Studentene ved barnehagelærerlærerutdanningen utvikler en mer positiv holdning til barn med særskilte behov fra de starter studiet til de avslutter studiet.

\section{Metode}

\section{Forsøkspersoner}

81 studenter ved barnehagelærerutdanningen deltok i undersøkelsen, 62 kvinner og 19 menn. Ved andre gangs måling (pretest) var det 63 studenter som deltok.

\section{Design}

Undersøkelsen ble gjennomført som et eksperiment der første måling skjedde noen uker etter studiets begynnelse, mens andre måling ble foretatt like før avsluttende eksamen.

\section{Måleinstrument}

Måleinstrumentet som ble utarbeidet for å måle studenters holdning til barn med særskilte behov, består av 18 items som alle har karakter av utsagn. Et vanlig item er: «Jeg mener jeg 
vil være aktiv i å legge til rette for barn med særskilte behov i min barnehage».

Spørreskjemaet på 18 items som intenderer å tappe eller måle «holdning til barn med særskilte behov», er en del av en større enhet i spørreskjemaet på til sammen 81 items.

Skåringsregler: Hvert item består av 5 svaralternativer som varierer fra «sterkt uenig», «uenig», «nøytral», «enig» og «sterkt enig». «Sterkt uenig» får skåreverdi 1, «uenig» skåreverdi 2 og så videre. Maksimal skåreverdi for en person på de 18 items blir 90, mens minimumsverdi blir 18: en variasjonsbredde på 72 .

Reliabilitet: Måleinstrumentets reliabilitet ble kartlagt ved hjelp av Cronbach’s Alpha, der alpha-koeffisienten var 0,71. Koeffisienten er noe lav, men tilfredsstillende for gruppesammenligninger.

\section{Gjennomføring av eksperimentet}

Studentene tok stilling til de samme items ved studiets begynnelse (pretest) og like før avsluttende eksamen ved studiets slutt (posttest). Det ble presisert at deltakelse var frivillig, at alle opplysningene ville bli anonymt behandlet og at det ikke var snakk om riktige eller gale svar på spørreskjemaet, men et ønske om å få fram studentenes eget synspunkt på ulike utsagn. Studentene gikk i to separate klasser på vel 40 studenter i hver klasse, slik at utfyllingen av spørreskjemaet foregikk i to forskjellige klasser med kort mellomrom.

Frafall: Ved posttest-kartleggingen var det i alt 63 studenter som deltok. Det var 18 studenter som enten ikke var til stede den dagen posttest-kartleggingen ble gjennomført, eller som av en eller annen grunn hadde avbrutt studiet. Det er ikke noe som tyder på at dette frafallet skulle innvirke på designens indre validitet, det vil si i hvilken grad man kan tilsi at den ventede endring i holdning til barn med særskilte behov kan tilskrives studiet og ikke andre forhold.

Selve eksperimentet: Selve eksperimentet eller intervensjonen i denne studien er den samlede undervisning studentene mottar i studiet, inklusive praksisperioden. Forsøksleder har selvsagt ingen innflytelse på denne påvirkningen studentene utsettes for, som i designet har karakter av intervensjon.

\section{Analysemetode}

Alle data som ble samlet inn, er lagt inn på statistikksystemet SPSS, og endringene fra 1. til 2. gangs måling ble signifikanstestet ved hjelp av t-test for korrelerte data.

\section{Resultater}


Tabell 1. Forskjell i skårer på holdning til barn med særskilte behov fra studiets start og etter 3 år ved studiets slutt.

\begin{tabular}{|c|c|c|c|c|}
\hline & Pre-test & Post-test & Differanse & t \\
\hline M & 44.72 & 50.68 & 5.96 & 7.18 \\
\hline Sd & 4.90 & 4.98 & & \\
\hline N & 81 & 63 & & \\
\hline
\end{tabular}

Resultatene viste at det skjedde en markert økning i gjennomsnittlig skåreverdi på holdningsskalaen fra pre-test til post-test, en økning på nesten 6 hele poeng, se tabell 1. Denne markerte forskjellen er i ventet retning og er signifikant på 0.001-nivået, noe som t-testen også indikerer.

Resultater der kvinner og menn vurderes mot hverandre

Tabell 2. Forskjell i skårer på holdning til barn med særskilte behov fra studiets start og etter 3 år ved studiets slutt mellom kvinner og menn

\begin{tabular}{|l|c|c|c|c|}
\hline & Pre-test & Post-test & Differanse & t \\
\hline M - kvinner & 45.16 & 50.84 & 4.84 & 4.99 \\
\hline Sd & 5.03 & 5.29 & & \\
\hline $\mathbf{N}$ & 62 & 51 & & 4.88 \\
\hline $\mathbf{M}-\mathbf{m e n n}$ & 43.26 & 50.00 & 6.74 & \\
\hline Sd & 4.20 & 3.43 & & \\
\hline $\mathbf{N}$ & 19 & 12 & & \\
\hline
\end{tabular}


Av tabellen framgår det at de 62 kvinnelige studentene hadde noe høyere holdningsskåre (M $=45.16)$ enn de 19 mennene $(M=43.26)$ i pre-testen. Denne forskjellen er nesten borte ved post-test. Resultatet indikerer at de kvinnelige studentene ved studiestart er noe mer positive til barn med særskilte behov enn menn, mens forskjellen gradvis utviskes i løpet av studietiden. Både kvinnelige og mannlige studenter framviser en markert signifikant økning i positive holdningsskårer. Menn framviser imidlertid den største økningen i skårer på holdning til barn med særskilte behov, en økning på hele 6.74 i M-verdi.

\section{Resultater der materialet deles $i$ høy og lav alder}

For å undersøke aldersvariabelen ble den dikotomisert. Det vil si at aldersvariabelen ble todelt etter medianen både i pre- og post-test. Høy alder er studenter som er 23 år eller eldre, mens lav alder er studenter i alderen 18-23 år.

Tabell 3. Forskjell i skårer på holdning til barn med særskilte behov ved pretest og posttest mellom studenter med høy og lav alder.

\begin{tabular}{|l|c|c|c|c|}
\hline & Pre-test & Post-test & Differanse & T \\
\hline M - høy alder & 44.61 & 49.31 & 4.70 & 4.12 \\
\hline Sd & 5.07 & 4.15 & & \\
\hline N & 36 & 29 & & 6.11 \\
\hline M - lav alder & 44.80 & 51.85 & 7.05 & \\
\hline Sd & 4.81 & 5.37 & & \\
\hline N & 45 & 34 & & \\
\hline
\end{tabular}

Tabell 3 viser at studentene med lav alder (18-23 år) framviser den største økning i skåreverdi på holdning til barn med særskilte behov; en økning på hele 7.05 poeng som i størrelse er betydelig mer enn et standardavvik. Studenter med høy alder (23 år eller mer) framviser også en signifikant markert økning i skåreverdi på holdning til barn med særskilte behov. Ved studiestart var forskjellen i holdning mellom studentgruppene høy og lav alder relativ lik.

Årsaken til at de yngste studentene har hatt størst økning i holdningsskåre i løpet av studieløpet kan ikke forklares av dette materialet. En mulig årsak kan være at de yngste studentene er mest påvirkelige i holdningssammenheng; det vil si at den opprinnelige holdningen til barn med særskilte behov er noe mindre fastlåst i utgangspunktet blant de yngste studentene enn holdningen blant de eldste studentene. 


\section{Diskusjon}

Resultatene gir klar støtte til hypotesen om at studentene ved barnehagelærerutdanningen utvikler en mer positiv holdning til barn med særskilte behov fra de starter studiet til de avslutter studiet. Denne markerte økningen i positiv holdning gjelder uavhengig av studentenes alder og kjønn.

Resultatene skal imidlertid drøftes med utgangspunkt i validitetsbegrepet. Validitet kjennetegnes ved hvor sikkert en kan foreta ulike typer av slutninger og hvilke trusler eller feilkilder som gjelder for de ulike validitetstypene. Shadish, Cook og Campbell (2002) opererer med fire typer av validitet som er statistisk validitet, indre validitet, begrepsvaliditet og ytre validitet.

Ad statistisk validitet: Statistisk validitet eller resultatvaliditet gjelder statistiske slutninger relatert til i hvilken grad resultatene er systematiske og ikke tilfeldige og at resultatene er av en rimelig størrelsesorden. I denne studien framkommer meget klare forskjeller i holdning til barn med særskilte behov fra studiestart til studieslutt uavhengig av kjønn og alder på studentene. En kan av den grunn trekke den slutning at studien har relativ høy grad av statistisk validitet.

Ad indre validitet: Indre validitet gjelder sikkerhet i kausale slutninger; det vil si i hvilken grad en kan slutte at det er undervisningsopplegget som har ført til holdningsendringen og ikke utenforliggende faktorer eller trusler som for eksempel tid (man endrer seg med tiden), aktuelle TV-programmer som er relatert til holdninger til barn med særskilte behov og lignende. Denne studien har ikke tilfredsstillende kontroll med slike utenforliggende faktorer eller trusler da studien ikke har noen kontrollgruppe. Til tross for manglende kontrollgruppe så kan man på bakgrunn av den store holdningsendringen slutte at den indre validiteten er tilfredsstillende, men noe usikker.

Ad begrepsvaliditet: Begrepsvaliditet gjelder i hvilken grad man kan slutte at årsaksfaktoren (her undervisningen over tre år) og effektfaktoren (her måleinstrumentet for holdning til barn med særskilte behov) tapper eller måler de relevante begreper på en sikker måte. I denne studien kan det ikke sluttes noe om årsaksfaktoren eller undervisningen annet enn at den skal ha fulgt forskrift til rammeplanen for barnehagelærerutdanningen.

Når det gjelder måleinstrumentet for holdning til barn med særskilte behov, så viser interkorrelasjonene mellom de ulike item (Cronbach's alpha) at samsvaret mellom dem kunne vært høyere for å oppnå en mer tilfredsstillende begrepsvaliditet. Dette tilsier at begrepsvaliditeten kan sies være tilfredsstillende for gruppesammenligninger, men noe 
usikker.

Ad ytre validitet: Ytre validitet gjelder i hvilken grad man kan generalisere funnet til andre undervisningsinstitusjoner i barnehagelærerutdanning, og om effekten av holdningsendringen varer over tid. I denne studien er det ikke fortatt noe tilfeldig utvalg av utdanningsinstitusjoner slik at noen sikker slutning om at resultatene er gyldige også for andre institusjoner, ikke kan foretas. I den grad barnehagelærerutdanningen der informantene var studenter, ikke nevneverdig skiller seg fra de andre utdanningsinstitusjonene i landet, så kan man slutte at resultatet kan generaliseres til de andre utdanningsinstitusjonene da de følger samme forskrift til rammeplan for barnehagelærerutdanningen som landets øvrige utdanningsinstitusjoner. Generalisering over tid kan ikke foretas da en slik oppfølging ikke er foretatt.

\section{Avsluttende kommentar}

I «Forskrift om rammeplan for barnehagelærerutdanning» (Kunnskapsdepartementet 2012) § 1 «Virkeområde og formål» står blant annet følgende, sitat: «Utdanningen skal vektlegge det økte mangfoldet $\mathrm{i}$ barnehagen, herunder økt andel barn under tre år, flere barn med særskilte behov og flere flerspråklige barn». Her framgår det ganske klart at den treårige utdanningen har som et klart formål at studentene gjennom utdanningsperioden skal utvikle positive holdninger til barn generelt og positive holdninger til funksjonshemmede eller barn med særskilte behov, spesielt. Resultatene fra denne undersøkelsen viste en markert økning i barnehagelærernes positive holdninger til barn med særskilte behov i løpet sitt treårige studieforløp. Positive holdninger hos ansatte i barnehagen til barn med særskilte behov er en viktig faktor for at barn med behov for ekstra hjelp og støtte skal trives og inkluderes godt i barnegruppa (Monsen \& Fredrickson 2004). Andelen barn med behov for spesialpedagogisk hjelp i barnehagen har økt jevnt de siste fem årene, og i 2018 var tallet oppe i 3,2 prosent (Udir.no 2018). Dette innebærer at det er mange barn rundt om i barnehagene som har behov for voksne med positive holdninger som ser barnet og som kan gi kvalitativt gode tiltak for barn med behov for spesialpedagogisk tilrettelegging. Rammeplanen for barnehagen viser til at barnehagen «skal sørge for at barn som trenger ekstra støtte, tidlig får den sosiale, pedagogiske og/eller fysiske tilretteleggingen som er nødvendig for å gi barnet et inkluderende og likeverdig tilbud» $(2017$, s. 26).

Av barnehagens grunnbemanning, det vil si ansatte som jobber direkte med barna, så er en tredjedel av de ansatte uten høyere utdanning eller fagarbeiderutdanning (Udir.no 2018). Når effekten av denne undersøkelsen viser en så klar forskjell i holdning til barn med 
særskilte behov i løpet av studentenes tre-årige studieforløp, kan det stilles spørsmål ved den utstrakte bruken av ufaglærte assistenter i barnehagen som kanskje ikke har de positive holdningene som er ønskelige. Når antallet ufaglærte assistenter i barnehagen er så høyt, er dette bekymringsfullt for de barna som trenger ekstra hjelp og støtte. Det vil da være svært viktig at barnehager jevnlig bruker refleksjon for å jobbe med egne holdninger. I rammeplanen påpekes nettopp dette, at «personalet må reflektere over egne holdninger for best mulig å kunne formidle og fremme likeverd og likestilling» (Falck-Pedersen \& Iversen 2018, s. 12).

\section{Litteratur}

Allport, Gordon Willard (1935). Attitudes. I C. Murchison (Red.), Handbook of social psychology (s. 798-884). Worcester, MA: Clark University Press.

Arnold, John, Cooper, Cary \& Robertson, Ivan (1995). Work Psychology: Understanding Human Behaviour in the Workplace. London: Pitman Publishing.

Avramidis, Elias, Bayliss, Phil \& Burden, Robert (2000). A Survay into Mainstream Teachers`Attitudes Towards the Inclusion of Children with Special Educational Needs in the Ordinary School in one Local Education Authority. Educational Psychology, 20(2), s. 191-211. https://doi.org/10.1016/s0742-051x(99)00062-1

Bekle, Bruna (2004). Knowledge and attitudes about Attention-Dedicit Hyperactivity Disorder (ADHD): A comparison between practicing teachers and undergraduate education students. Journal of Attention Disorders, 7(3), s. 151-161. https://doi.org/10.1077/108705470400700303

Bogardus, Emory Stephen (1931). Fundamentals of social psychology. New York: Century.

Brook, Uzi, Watemberg, Nathan \& Geva, Diklah (2000). Attitude and knowledge of attention deficit hyperactivity disorder and learning disability among high school teachers. Patient Education and Counseling, 40(3), s. 24-252. https://doi.org/10.1016/s07383991(99)00080-4

Bush, Tor \& Wennes, Grete (2012). Holdninger til markedsløsninger: organisasjonsidentitet og verdiorientering. Beta, 26(1), s. 20-39. Hentet fra

https://www.idunn.no/sok\#?q=Holdninger $\% 20$ til $\% 20$ markedsl $\%$ C3\%B8sninger:\%20o rganisasjonsidentitet $\% 200 \mathrm{o} \% 20$ verdiorientering

Cambell, Donald Thomas (1950). The indirect assessment of social attitudes. Psychological Bulletin, 47(1), s. 15-38. https://doi.org/10.1037/h0054114

English, Horac Bidwell, \& English, Ava Champney (1958). A comprehensive dictionary of psychological and psychoanalytic terms: A guide to usage. New York: McKay.

Festinger, Leon (1957). A theory of cognitive dissonance. Stanford, Calif: Standford University Press.

Fishbein, Martin (1967). Readings in attitude theory and measurement. New York: John Wiley and Sons.

Hilgard, Ernest Ropiequet \& Atkinson, Richard Chatham (1967). Introduction to psychology 
(4. utg.). New York: Harcourt and Brace.

Hwang, Yoon-Suk \& Evans, David (2011). Attitudes Towards Inclusion: Gap between belief and practice. International Journal of Special Education, 26(1), s. 136-146.

https://www.researchgate.net/publication/258520436_Attitudes_towards_inclusion_G aps between belief and practice

Katz, Daniel (1960). The functional approach to the study of attitudes. Public Opinion Quaerterly, 24(2), s. 163-205. https://doi.org/10.1086/266945

Kunnskapsdepartementet (2012). Nasjonal forskrift om rammeplan for barnehageloererutdanning. Hentet fra

https://www.regjeringen.no/no/dokumenter/nasjonal-forskrift-om-rammeplan-forbarn/id684087/

Lines, Rune (2005). The structure and function of attitudes toward organizational change. Human Resource Development Review, 4(1), s. 8-32.

https://doi.org/10.1177/1534484304273818

Monsen, Jeremy Jey \& Fredrickson, Norah (2004). Teachers’ Attitudes Towards Mainstreaming and their Pupils'Perceptions of their Classroom Learning Environement. Learning Environments Research, 7(2), s. 129-142. https://doi.org/10.1023/B:LERI.0000037196.62475.32

Park, Meungguk, Chitiyo, Morgan \& Choi, Yun Seok (2010). Examining pre-service teachers ' attitudes towards children with autism in the USA. Journal of Research in Special Educational Needs, 10(2), s. 107-114.

https://doi.org/10.1111/j.1471-3802.2010.01150.x

Falck-Pedersen Turid \& Iversen Anne-Brit (2018). Rammeplan for barnehagen: Innhold og oppgaver; Fastsatt av Kunnskapsdepartementet 24. april 2017 med hjemmel i lov 17. juni 2005 nr. 64 om barnehager (barnehageloven) \& 2 syvende ledd (3. utg.). Oslo: Pedlex.

Secord, Paul Frank \& Beckman, Carl Ward (1969). Social Psychology. New York: McGrawHill.

Shadish, William Raymond, Cook, Thomas Dixon. \& Campbell, Donald Thomas (2002). Experimental and quasi-experimental designs for generalized causal inference. Boston: Houghton Mifflin.

Thurstone, Louis. Leon (1946). Comment. American Journal of Sociology, 52, s. 39-50. Triandis, Harry Charalambos (1971). Attitude and attitude change. New York: John Wiley and Sons.

Udir.no (2018). Tall og analyse fra barnehager. Hentet fra https://www.udir.no/tall-ogforskning/statistikk/statistikk-barnehage/tall-og-analyse-av-barnehager-2018/barn-ibarnehagen/

Vakola, Maria, Tsaousis, Ioannis \& Nikolaou, Ioannis (2004). The role of emotional intelligence and personality variables on attitudes toward organizational change. Journal of Managerial Psychology, 19(2), s. 88-110. https://doi.org/10.1108/02683940410526082 
